\title{
An Overview on Cotton Leaf Curl Disease: An Emerging Potential Threat to Cotton
}

\author{
Anupam Maharshi', N.K. Yadav ${ }^{1}$, Praveen Kumar ${ }^{3}$, Prachi Singh ${ }^{2 *}$, \\ Jagjeet Singh $^{2}$ and Arpan Mukherjee ${ }^{2}$ \\ ${ }^{1}$ Cotton Research Station, CCS Haryana Agricultural University, Sirsa -125055, India \\ ${ }^{2}$ Department of Mycology and Plant Pathology, Institute of Agricultural Sciences, \\ BHU, Varanasi-221005, India \\ ${ }^{3}$ Cotton Section, Department of Genetics and Plant Breeding, CCS Haryana Agricultural \\ University, Hisar -125055, India \\ *Corresponding author
}

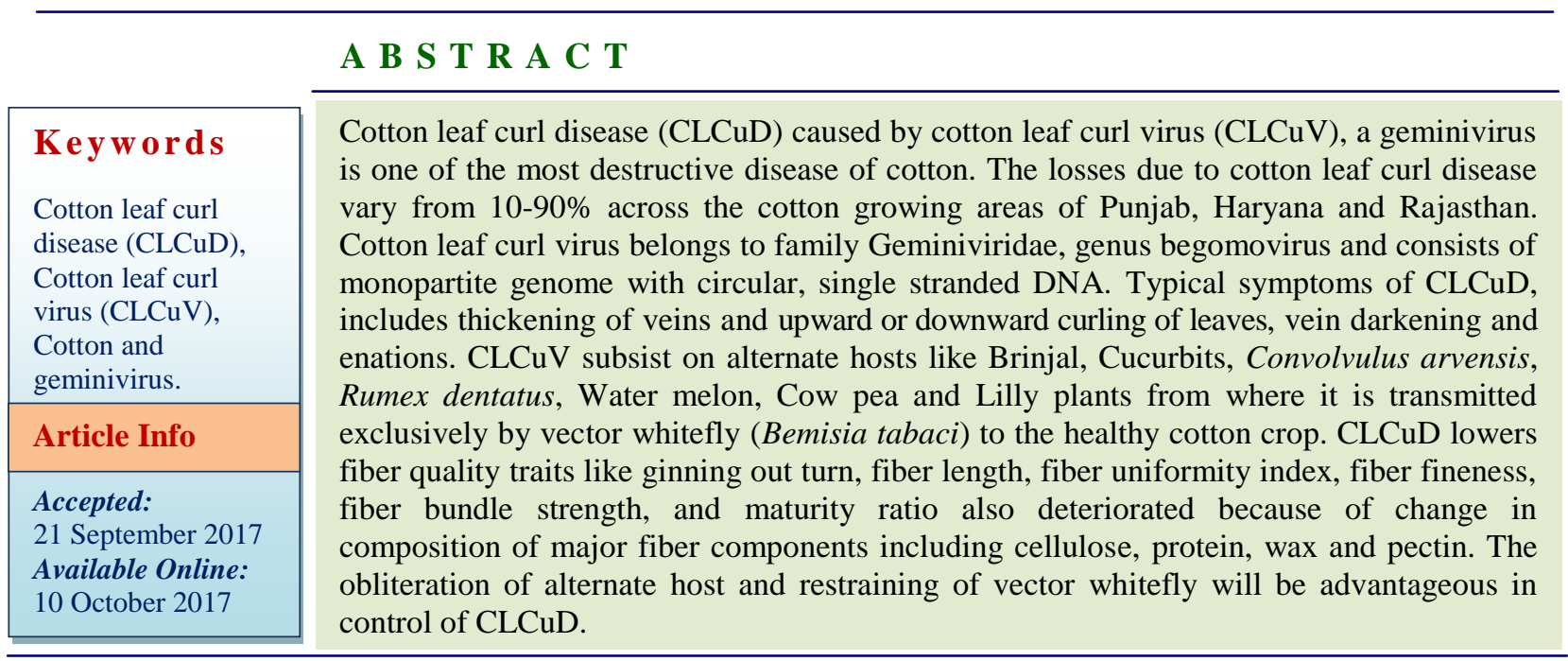

\section{Introduction}

Cotton has an eminent position in Indian agricultural, industrial and economic development. In India main cotton growing belt is north-western region including Punjab, Haryana and Rajasthan. In India, it occupies an area of about 118.81 lakh ha with total production 352 lakh bales and average yield is $503 \mathrm{~kg} /$ ha (Anonymous, 2016). Several constraints are responsible for decreased production as well as productivity of cotton in India among them cotton leaf curl disease has emerged as one of the most important one. Among four cotton cultivated species, only two viz., G. hirsutum L. and G. arboreum L. are grown in Haryana. G. hirsutum L. is susceptible whereas, G. arboreum is resistant to Cotton leaf curl disease (CLCuD). The disease is caused by whitefly transmitted Geminivirus which was first noticed in Nigeria on Gossypium peruvianum and $G$. vitifolia (Farquharson, 1912). In India the disease was first reported on $G$. barbadense at 
Indian Agricultural Research Institute, New Delhi in 1989, followed by American cotton ( $G$ hirsutum) in Sriganganagar district of Rajasthan in 1993 (Ajmera, 1994)

Cotton leaf curl disease (CLCuD) caused by single stranded circular Geminivirus consisting of DNA-A and two satellites, exclusively transmitted by the insect vector whitefly (Bemisia tabaci). It belongs to genus Begomovirus, and is transmitted by its exclusive vector whitefly (Bemisia tabaci) in circulative and persistent manner. Apart from cotton, the virus can infect several collateral and alternate hosts that act as source of inoculum for its spread from one season to the other by its vector i.e. whitefly. However, symptoms of the disease have not been properly defined on weeds. A number of weeds as well as other hosts harbour this virus in the off season and serve as the main source of primary inoculum for the development of disease on cotton. Identification of weeds which carrying $\mathrm{CLCuV}$ inoculum and its timely detection can help in rouging of weed plants to prevent further spread of the virus.

\section{Cotton Leaf Curl Virus}

A notorious group of the virus family Geminiviridae, causes major threat to cotton crop and a well-known threat is Cotton leaf curl disease (CLCuD) caused by Cotton leaf curl virus $(\mathrm{CLCuV})$, transmitted in persistent manner by whitefly i.e. Bemisia tabaci (Brown et al., 1995). CLCuV is most closely related to 'Old World' viruses such as Indian cassava mosaic and tomato yellow leaf curl. Seven diverse species of begomoviruses have been found which is associated with the $\mathrm{CLCuD}$ in the Indian subcontinent specifically Cotton leaf curl Multan virus (CLCuMV), Cotton leaf curl Rajasthan virus (CLCuRV), Cotton leaf curl Alabad virus (CLCuAV), Cotton leaf curl Kokhran virus (CLCuKV) and Papaya leaf curl virus
$(\mathrm{PaLCuV})$, Cotton leaf curl Bangalore virus (CLCuBV) associated with alphasatellite and betasatellite molecules (Mansoor et al., 2003b; Briddon 2003) and Cotton leaf curl Burewala virus (CLCuBuV) (Amrao et al., 2010).

PCR-mediated amplification showed the presence of a begomovirus named Cotton Leaf Curl Virus (CLCuV) in CLCuD-infected cotton. A smaller (approx. 1350 nucleotides) single stranded DNA molecule (termed DNA1) was shown to be associated with CLCuD (Mansoor et al., 1999). This molecule capable of self-replication in plant cells but requiring $\mathrm{CLCuV}$ for spread in plants as well as in insect transmission was shown to play no part in inducing symptoms. This DNA 1 shows high level of similarity to nanovirus components which encode the replication associated protein (RAP). Attempts to identify a second genomic component (DNABeta) were not successful earlier, suggesting that $\mathrm{CLCuV}$ is a monopartite begomovirus.

However, full length clones of CLCuV, although infectious, were unable to induce the symptoms typical of CLCuD in cotton and other host plants. This indicated that it requires one other factor to induce symptoms of the disease in plants (Briddon et al., 2001). The genome component designated DNA-A encodes viral functions required for replication and also plays an essential role in insect transmission. The second component encodes the products involved in movement within and between the cells in host tissues (Briddon et al., 2001).

However, a small number of begomoviruses such as CLCuV, Tomato yellow leaf curl virus (TYLCV), Ageratum yellow vein virus (AYVV) etc. have a monopartite genome. In monopartite begomoviruses, these genes are present in DNA-A. Recently a single stranded DNA molecule approximately 1350 
nucleotides in length has been isolated and identified which when coinoculated with the begomovirus to cotton, induces symptoms typical of CLCuD, including vein swelling, vein darkening, leaf curling and enations (Briddon et al., 2001; Briddon et al., 2003; Mansoor et al.,2003; Kirthi et al., 2004; Radhakrishnan et al., 2004). A distinct strain of cotton leaf curl Burewala virus (CLCuBV) also was identified in C49 isolate collected from CLCuD symptomatic cotton plant in Layyah district, Punjab. The newly identified strain of CLCuBV lacks an intact transcriptional activator protein (Shuja et al., 2014).

\section{Genome of CLCuV monopartite}

Genome of CLCuV is monopartite genome, but in some species of $\mathrm{CLCuV}$ small circular single-stranded DNA satellites are associated with some monopartite begomoviruses, including cotton leaf curl Multan virus (CLCuMV), tomato yellow leaf curl China virus (TYLCCV), and they have been shown to be important for the induction of disease symptoms (Briddon et al., 2001). DNA $\beta$ satellites are approximately $1350 \mathrm{bp}$ and require a helper virus for replication and encapsidation (Mansoor et al., 2003; Briddon \& Stanley, 2006). Analysis of DNA $\beta$ sequences has revealed a conserved organization consisting of a single complementary-sense gene $(\beta \mathrm{C} 1)$ an adeninerich region and a satellite-conserved region that carries sequence similarity to the Tomato leaf curl virus (ToLCV) satellite-DNA (Briddon et al., 2003). The DNA $\beta$ associated with cotton leaf curl disease (CLCuD) encodes a single protein called fiCl which is a pathogenicity determinant (Saeed et al., 2005). A new betasatellite DNA is reported that associated with the Cotton leaf curl Burewala virus infecting tomato plants in India influence on symptoms and viral accumulation (Kumar et al., 2013).

\section{Symptomatology of CLCuD}

Cotton leaf curl disease symptoms were first reported in Nigeria in G. Barbadense cotton (Farquharson, 1912). In 1924, similar symptoms were reported to be widespread in the Sudan cotton crop (Golding, 1930), Symptoms of cotton leaf curl virus disease may vary from variety to variety but a specific virus produces the same symptoms in different hosts (Kirkpartrick, 1931; Bedford et al., 1994).

Tarr (1951) reported spirally twisted petioles, fruiting branches and tall stems and elongated internodes in $G$. barbadense. Most varieties in Africa infected by CLCuGV exhibit dwarfing, overall stunting, reduced boll number and boll weight. Two types of vein thickening are produced by CLCuD i.e., main and small vein thickening. Main vein thickening was described by the dark green thickening of the distal end of the large veins of younger leaves while thickening of small veins was characterized by dark green or pale green thickening of fine veins of young leaves.

These irregular thickenings of veins gradually extended and resulting in more or less continuous reticulation of veins (Nour and Nour, 1964; Watkins, 1981). Begomoviruses generally produce three types of prominent symptoms: leaf curl, yellow vein and yellow or golden mosaic. Enation formation, thickening of veins and upward or downward curling of leaves are typical symptoms of CLCuD (Mansoor et al., 1993).

The typical symptoms of the disease include upward or downward leaf curling, dark green veins, vein thickening and enation that appeared in bead-shaped, small fine leaf like structures on the under surface of the leaves (Bink, 1975; Briddon and Markham, 2000). The severely affected plants have bushy appearance with dark green colour, short 
internodes without flowers and bolls (Chauhan, 2004).

\section{Alternate hosts of Cotton Leaf Curl Virus}

Nour and Nour (1964) observed leaf curl symptoms on Corchorus fasicularis, Phyllanthus niruri, Clitoria sp, Phaseolus vulgaris and Petunia. The important alternate hosts reported from Sudan are species of Gossypium, Hibiscus, Althaea, Sida, Malva, Malvaviscus, Abutilon, Lavatera and possibly Urena (EI and Salih, 1970). In Pakistan under field conditions CLCuV symptoms were observed on alternate hosts like Brinjal, Cucurbits ("Tinda", "Kali tori"), Convolvulus arvensis, Rumex dentatus, Water melon, Cow pea and Lilly plants (Anonymous, 1993). Alternate hosts play an important role in causing this virus to spread over cotton crop. They provide inoculum to the vector for transmitting the same in cotton. There are many ornamental plants and common weeds which have been found infected with whitefly- transmitted geminiviruses (Mansoor et al., 1998; Mansoor et al., 1999). Singh et al., (1994) reported appearance of the CLCuD on the Sidasps, Abutilon indicum, Hibiscus rosa-sinensis, and Althea roses on the basis of visual symptoms. In Phaseolus vulgaris, pepper, tomato and tobacco, transmission studies and ELISA showed the presence of $\mathrm{CLCuV}$ (Nateshan et al., 1996).

Cotton leaf curl virus disease CLCuD spread widely from the basal inoculums that are present in the off season in the form of weeds and other hosts (Monga et al., 2001). Radhakrishnan et al., (2001) conducted transmission studies on Okra, Hollyhock, Tomato, Physalis floridana, Nicotiana benthamiana and French bean to detect the presence of cotton leaf curl virus. DNA-A probe hybridization conducted on Hollyhock, Sida ageratum, China rose to detect the presence of CLCuV (Sharma and Rishi, 2003). Tribulus terrestris and Cuсumus spp. showed the presence of DNA-A and Beta DNA of CLCuV in their genome (Sivalingam et al., 2004). Corchorus acutangularis, Melilotus indica, Ageratum conyzoides were detected $\mathrm{CLCuV}$ positive on the basis of DNA-A \& DNA beta probe hybridization (Radhakrishnan et al., 2004). PCR using CP primer showed the presence of $\mathrm{CLCuV}$ genome in Tomato, Tobacco, Zinnia, Jungli pudina, Chilli, China rose, Okra, Sida alba, Sida sp., Achyranthes sp. and Clerodendron sp. (Kang et al., 2004, Monga et al., 2005). Convolvulus arvensis, Capsicum spp., Parthenium sps, Solanum nigrum, Digitaria arvensis, Lantana camara, Achyranthes aspera, Chenopodium album, Spinacea spp., Xanthium strumarium were also reported as host of $\mathrm{CLCuD}$ coat protein gene amplification (Monga et al., 2011).

\section{PCR for detection and diagnosis of viruses}

In general, PCR is very useful in detection and diagnosis of viruses, viroids and other plant pathogens. Geminiviruses are well studied due to its ease of detection and identification by PCR, as they replicate via double stranded, circular DNA intermediate, replicative form (Stanley, 1991). Which serve as a template for amplification by PCR. The genome constitute of number of regions which are highly conserved between viruses and hence can be used to design degenerate PCR primers (Rojas et al., 1993; Tan et al., 1995; Muniyappa et al., 2000). Degenerate oligonucleotide primers, designated for amplification of an approximately $500 \mathrm{bp}$ fragment of DNA-A of five well characterized whitefly transmitted geminiviruses were used in the polymerase chain reaction (PCR), to detect known or putative geminiviruses mostly infect seven plant species that are originally obtained from Europe, India, Africa and America (Deng et 
al., 1994). The sequence of a pair of degenerate primers suitable for the PCR mediated amplification of near full length genomes of Geminiviruses that infect dicotyledonous plants has been described (Bridon and Markham, 1994). The products of these amplifications were useful not only as diagnostic probes but also for the determination of DNA sequence and single cutting restriction endonuclease sites prior to cloning of viruses. Degenerate primers designed to amplify DNA-A of whitefly transmitted geminiviruses were used in PCR for amplification of viral DNA (Mansoor et al., 1998). A product of expected size was 1.4 were obtained from all these samples that confirmed the infection of whitefly transmitted Geminiviruses. A set of primers designed based on the conserved sequence of coat protein region were used for the detection of DNA-A in cotton leaf curl virus $(\mathrm{CLCuV})$ infected weeds and cotton plants using PCR technique (Monga et al., 2005). Similarly, primers Beta 1 and 2 designed to amplify DNA- $\beta$ were used (Monga et al., 2005). The cotton leaf curl virus specific primer precisely detected the virus in infected cotton as well as in symptom less plants by amplification of $771 \mathrm{bp}$ coat protein gene (Chakrabarty et al., 2005).

\section{Losses and appearance of CLCuD}

Cotton leaf curl disease is the most devastating natural calamity that reduces the quality and production of the cotton (Viveki et al., 2014). Disease is reported to cause huge loss in various regions for instance, considerable seed cotton yield reduction in Rajasthan (32.9 to 50.3\%), Punjab (10.5 to $92.2 \%$ ) and Haryana (39.4 to $81.4 \%$ ) states of north India has also been reported (Narula et al., 1999; Monga et al., 2001). Maximum seed cotton yield ( $\mathrm{q} / \mathrm{ha}$ ) was recorded in $\mathrm{Bt}$ hybrid SP 7007 BG (27.8) followed by Bioseed 6488 BGII (26.9) and SP 7007 BGII
(26.5). Percent maximum loss in seed cotton yield was observed in hybrid Jai BG (54.1) followed by MRC 7361 BG (48.8) and Solar 76 BG (46.8) (Monga et al., 2011).

Appropriate sowing time preferably midApril to mid-May results in decrease of disease incidence (Ghazanfar et al., 2007) as compared to delay in sowing from mid-May to June. Amid various management factors to boost up per acre yield of cotton, apposite genotype selection, optimal sowing time and higher plant density toning the ecological conditions of the region is the most important (Ali et al., 2004; Nadeem et al., 2010). Iqbal and Khan (2010) reported that increased plant spacing in the case of early sowing and decreased plant spacing under late sown conditions is effective in management of CLCuD. They also concluded that CLCuD infestation reached its maximum after 105 days of sowing and in case of late sown crop i.e. 15 June or later infestation becomes severe after 45 days of sowing. They recommended $15 \mathrm{~cm}$ plant spacing in order to manage CLCuD in the case of planting later than $15^{\text {th }}$ of June. CLCuD exhibited a negative and significant association with seed cotton yield, GOT, no of bolls (Saeed et al., 2014 and Farooq et al., 2013). CLCuV severely hampered the crop performance by delayed planting of cotton from 15th April; while increased the chances of disease incidence. It concluded that early sowing reduces the problem of $\mathrm{CLCuV}$ and enhanced cotton productivity (Ali et al., 2014). Due to CLCuD incidence fiber quality traits like ginning out turn, fiber length, fiber uniformity index, fiber fineness, fiber bundle strength, maturity ratio also deteriorated because of change in composition of major fiber components including cellulose, protein, wax and pectin (Farooq et al., 2014). Maximum $\mathrm{CLCuV}$ incidence was recorded within 30-45 days in late planting as compared to 105 days of early planted cotton. Delay in sowing 
cotton crop reduced seed cotton yield progressively (Hussain et al., 2015).

Cotton leaf curl disease (CLCuD) is one of the key threat to the cotton crop, leading to about $10-90 \%$ loss. Control of vector whitefly by applying relevant cultural, mechanical and biological approaches has been found effective to manage $\mathrm{CLCuV}$. Numerous studies has been conducted for the detection of alternate/collateral hosts of $\mathrm{CLCuV}$ and screening of resistant germplasm against $\mathrm{CLCuV}$, but not fully understood. Therefore, there is dire need to identify the primary source of inoculum i.e. collateral and alternate weeds/hosts, assessment of losses and source of resistance to $\mathrm{CLCuD}$ for its mitigation and management.

\section{References}

Ajmera, B.D., 1994. Occurrence of leaf curl virus on American Cotton (G. hirsutum) in north Rajasthan. Paper presentation, National Seminar on Cotton Production Challenges in $21^{\text {st }}$ Century, April 18-20 Hisar. India.

Ali, H., Hussain, G.S., Hussain, S., Shahzad. A.N., Ahmed, S., Javeed, H.M.R., Sarwar, N. 2014. Early sowing reduces cotton leaf curl virus occurrence and improves cotton productivity.Cercetări Agronomice în Moldova. 47(4): 71-81

Ali, M., Din, Q.M., Ali, M.A., Sabir, S., Ali, L. 2004. Cotton yield as influenced by different sowing dates under the climatic conditions of Vehari-Pakistan. Int. J. Agric. Biol. 6(4): 644-646.

Amrao, L., Akhtar, S., Tahir, M.N., Amin, I.,Briddon, R.W. and Mansoor, S. 2010. Cotton leaf curl disease in Sindh province of Pakistan is associated with recombinant begomovirus components. Virus Res.153: 161-165.

Anonymous, 1993. A Research compendium of cotton leaf curl viral disease and its management. PARC, Islamabad, $\mathrm{P} 62$. Anonymous, 2016. AICCIP Annual Report (2014-15), All India Coordinated Cotton Improvement Project.

Bedford, I.D., Briddon, R.W., Brown, J.K., Rosell, R.C. and Markham, P.G. 1994. Geminivirus transmission and biological characterisation of Bemisia tabaci (Gennadius) biotypes from different geographic regions. Ann. of Appli. Biol. 125(2): 311-325.

Bink, F.A., 1975. Leaf curl and mosaic diseases of cotton in central Africa. Emp. Cott. Growing rev.52: 133-41.

Briddon, R.W., 2003. Cotton leaf curl disease, a multi component begomovirus complex. Mol Pl. Patho. 4:427-434.

Briddon, R.W., and Markham, P.G. 1994. Universal primers or dicot-infecting gcminiviruses. Mol. Biotec., I: 202-205.

Briddon, R.W., and Stanley, J. 2006. Subviral agents associated with plant single stranded DNA viruses. Virology. 344(1): 198-210.

Briddon, R.W., Mansoor, S., Bedford, I.D., Pinner, M.S. and Markham, P.G. 2000. Clones of cotton leaf curl geminivirus induce symptoms a typical of cotton leaf curl disease. Virus Genes 20:17-24.

Briddon, R.W., Mansoor, S., Bedford, I.D., Pinner, M.S., Saunders, K., Stanley, J., Zafar, Y., Malik, K.A. and Markham, P.G. 2001. Identification of DNA components required for induction of cotton leaf curl disease. Virology, 285: 234-243.

Brown, J.K., Frohlich, D.R. and Rosell, R.C. 1995. The sweet potato or silver leaf whitefly; biotype of Bemisia tabaci or a species complex. Ann Rev. of Entomol, 40: 511-534.

Chakrabarty, P.K., Sable, S., Monga, D. and Mayee, C.D. 2005. Polymerase chain reaction-based detection of Xanthomonas axonopodis pv malvacearum and cotton leaf curl virus- 
Indian J. Agric. Sci, 75: 524-27.

Chauhan, M.S., 2004. Researches in cotton pathology-An overview at CCS, HAU 1967-2004, pp. 35-50.

Deng, D., McGrath, P.F., Robinson, D.J. and Harrison, B.D. 1994. Detection and differentiation of whitefly-transmitted geminiviruscs in plants and vector insects by the Polymerase Chain reaction with degenerate primers. Ann. of Appl Bio., 125: 327-336.

El-Nur, E., and Abu Salih, H.S. 1970. Cotton leaf curl virus disease. PANS, 16: 121131.

Farooq, J., Anwar, M., Riaz, M., Mahmood, A., Farooq, A., Iqbal, M., Saeed, F. And Shahid, M. 2013. Association and path analysis of earliness, yield and fiber related traits under cottonleaf curl virus $(\mathrm{CLCuV})$ intensive conditions in Gossypium hirsutum L. Pl Knowledge J., 2(1): 43-50.

Farooq, J., Farooq, A., Riaz, M., Shahid, M.R., Saeed, F., Iqbal, M.S., Hussain, T., Batool, A. and Mahmood, A. 2014. Cotton leaf curl virus disease a principle cause of decline in cotton productivity in Pakistan (a mini review) Canadian J. of Pl. Protection, 2(1): 9-16.

Farquharson, C.O., 1912. A report of the mycologist. A report Agric. Deptt. Nigeria. In Siddique MA and Hungus LC (Eds) Cotton growth in Gezira environment. W Haffer and Sons Ltd. Cambridge England. p 106.

Ghazanfar, M.U., Sahi, S.T., Ilyas, M.B. and Randhawa, M.A. 2007. Influence of sowing dates on $\mathrm{CLCuV}$ incidence in some cotton varieties. Pak J Phytopathol, 19(2): 177-180.

Golding, F.B., 1930. A vector of leaf curl of cotton in Southern Nigeria. Emp. Cott. Growing Rev., 7:120-6.

Hussain, S., Mahmood, T., Tahir, M. Mahmood, H.T. and Afzal M.N. 2015. Differential Effect of Planting Time on
Cotton Leaf Curl Disease (CLCuD) and Yield of Cotton Variety Cim-598 (Gossypium Hirsutum L.) Int. J. of Novel Res. in Life Sci., 2(1): (1-7).

Iqbal, M., and Khan, M.A. 2010. Management of cotton leaf curl virus by planting time and plant spacing. $A A B$ Bioflux, 2(1).

Kang, S.S., Akhtar, M., Cheema, S.S., Malathi, V.G. and Radhakrishnan, G. 2004. Quick detection of cotton leaf curl virus. Indian Phytopathol, 57: 24546.

Kirkpatrick, T.W., 1931. Further studies of leaf-curl of cotton in the Sudan. Bull Ent Res., 12: 323-363.

Kirthi, N., Priyadarshini, C.G.P., Sharma, P., Maiya, S.P., Hemalatha, V., Sivaraman, P., Dhawan, P., Rishi, N. and Savithri, H.S. 2004. Genetic variability of begomoviruses associated with cotton leaf curl disease originating from India. Arch. of Virol. 149: 2047-2057.

Kumar, J., Gunapati, S., Singh, P.S., Kumar, A., Lalit, A., Sharma, N. C., Puranik, R., Tuli, R. 2013.A new beta satellite reported associated with cotton leaf curl Burewala virus infecting tomato in India: influence on symptoms and viral accumulation. Arch Virol, 158:13491353.

Mansoor, S., Berdford, I., Pinner, M.S., Stanley, J. and Markham, P.G. 1993. A whitefly transmitted geminivirus associated with cotton leaf curl disease in Pakistan. Pak. J. Bot., 25(1): 105107.

Mansoor, S., Briddon, R.W., Zafar, Y. and Stanley, J. 2003. Geminivirus disease complexes: an emerging threat. Trends Plant Sci., 8: 128-134.

Mansoor, S., Briddon, R.W., Zafar, Y. and Stanley, J. 2003b. Geminivirus disease Briddon R.W. (2003) Cotton leaf curl disease, a multi component begomovirus complex. Mol Pl. Patho, 
4:427-434.

Mansoor, S., Khan, S.H., Bashir, A., Saeed, M., Zafar, Y., Malik, K.A., Briddon, R., Stanley, J. and Markham, P.G. 1999. Identification of a novel circular single stranded DNA associated with cotton leaf curl disease in Pakistan. Virology, 259: 190-199.

Mansoor, S.M., Hussain, S.H., Khan, A. Bashi, A.B., Leghari, G.A., Panwar, W.A., Siddique, Y., Zafar and Malik K.A. 1998. Polymerase chain reaction based detection of cotton leaf curl and other whitefly transmitted geminiviruses from Sindh. Pak. J. Biol. Scci., 1: 39-43.

Monga, D., Chakrabarty, P.K., and Kranthi, R. 2011. Cotton leaf curl virus disease in India Recent status and management strategies Presented in 5th meeting of Asian Cotton Research and Development Network (Lahore, Feb 2325).

Monga, D., Kumar, R. and Kumar, M. 2005. Detection of DNA A and satellite (DNA beta) in cotton leaf curl virus (CLCuV) infected weeds and cotton plants using PCR technique. J. Cotton Res. Dev., 19: 105-108.

Monga, D., Narula, A.M., Raj, S. 2001. Management of cotton leaf curl virus- A dreaded disease in north India. Paper published in Book of papers of National seminar on Sustainable cotton production to meet the future requirement of industry. Organised by Kapas Vikas Nideshalya, Directorate of cotton development, Government of India. pp. 112-115.

Munniyappa, V., Venkatesh, H.M., Ramappa, H.K., Kulkami, RS, Zairian, M., Tabra, C.Y., Ghanim, M.and Czosnek, H. 2000. Tomato leaf curl virus from Bangalore Golan- associated with a begomovirus disease complex of Digitaria arvensis, a weed host. Nucleic acids Res., 8: 4321-4325.

Nadeem, M.A., Ali, A., Tahir, M., Naeem, M., Chadhar, A.R. and Ahmad, S. 2010. Effect of nitrogen levels and plant spacing on growth and yield of cotton. Pak. J. Life Soc. Sci., 8(2): 121124.

Narula, A.M., Monga, D., Chauhan, M.S. and Raj, S. 1999. Cotton leaf curl virus disease in India-The Challenge ahead. $J$. Cotton Res. Dev., 13: 129-138.

Nateshan, H.M., Muniyappa, V., Swanson, M.M. and Harrison, B.D. 1996. Host range, vector relations and serological relationships of cotton leaf curl virus from southern India. Ann. appl. Biol., 128: 233-244.

Nour, M., and Nour, J.J. 1964. Identification, transmission and host range of leaf curl virus infecting cotton in Sudan. Emp. Cotton Growers Rev., 41: 27-37.

Radhakrishnan, G., Malathi, V.G. and Varma, A. 2001. Novel features of cotton leaf curl virus disease in India. In. 3rd International Gemini Virus Symposium, July 24-28, 2001, John Innes Centre, Norwich, Norfolk, U. K., p53.

Radhakrishnan, S., Malathi, V.G. and Varma, A. 2004. Biological characterization of an isolate of cotton leaf curl Rajasthan virus from northern India and identification of sources of resistance. Indian Phytopathol, 57: 174-180.

Radhakrishnan, S., Malathi, V.G. and Varma, A. 2004. Biological characterization of an isolate of cotton leaf curl Rajasthan virus from northern India and identification of sources of resistance. Indian Phytopathol, 57: 174-180.

Rojas, J.R., Gilbertson, R.L., Russell, D.R., Maxwell, D.P. 1993. Use of degenerate primers in the polymerase chain reaction to detect whitefly-transmitted geminiviruses. Pl. Dis.77:340-347.

Saeed, F., Farooq J., Mahmood A., Riaz M., Hussain T. and Majeed A. 2014. Assessment of genetic diversity for 
Cotton leaf curl virus (CLCuD), fiber quality and some morphological traits using different statistical procedures in Gossypium hirsutum L. Aust. J. of Crop Sci., 8(3):442-447.

Saeed, M., Behjatnia, S.A., Mansoor, S., Zara, $Y$ Hasnain, S. and Rezaian, M. A. 2005. A single complementary-sense transcript of a geminiviral DNA $b$ satellite is determinant of pathogenicity. Mol. Pl. Microbe Interact. 18: 7-14.

Sharma, P., and Rishi, N. 2003. Host range and vector relationships of cotton leaf curl virus from northern India. Indian Phytopath. 56: 496-499.

Shuja, M.N., Briddon, R.W. and Tahir, M. 2014. Identification of a distinct strain of cotton leaf curl Burewala virus. Arch Virol DOI 10.1007/s00705-014-2097-0.

Singh, J., Sohi, A.S., Mann, H.S. and Kapur, S.P. 1994. Studies on whitefly B. tabaci (Genn.) transmitted cotton leaf curl virus disease in Punjab. J. Insect Sci., 7: 194-198.

Sivalingam, P.N., Padmalatha, K.V., Mandal, B., Monga, D., Ajmera, B.D. and
Malathi, V.G. 2004. Detection of begomoviruses in weeds and crop plants in and around cotton field surveillance: Disease forecasting and management held at IARI, New Delhi, February 1921, 2004. Souvenir and abstract, p.36.

Stanley, J., 1991. The molecular determinants of geminivirus pathogenesis. Seminar in virology, 2:139-150.

Tan, P.H.N., Wong, S.M., Wu, M., Bedford, I.D., Saunders, K. and Stanley, J. 1995. Genome organisation of ageratum yellow vein virus, a monopartite whitefly transmitted geminivirus isolated from a common we. J. General Virol., 76(12): 2915-2922.

Viveki K., Rudani P., Shah, V. 2014. Detection of Cotton Leaf Curl Disease. Int. J. Advance Engg. And Res. Develop. (IJAERD) Special Issue, 1(4).

Watkins, G.M., 1981. Compendium of cotton diseases. The American Phytopathological Society, 3340. Pilot knob Road, Minnesota USA, 87p.

\section{How to cite this article:}

Anupam Maharshi, N.K. Yadav, Praveen Kumar, Prachi Singh, Jagjeet Singh and Arpan Mukherjee. 2017. An Overview on Cotton Leaf Curl Disease: An Emerging Potential Threat to Cotton. Int.J.Curr.Microbiol.App.Sci. 6(10): 2154-2162. doi: https://doi.org/10.20546/ijcmas.2017.610.255 